\title{
Islamic corporate governance and performance based on maqasid sharia index- study in Indonesia
}

\author{
Hasan Mukhibad $^{1 *}$, Mahameru Rosy Rochmatullah², Warsina $^{3}$, Rahmawati $^{4}$, Doddy Setiawan $^{5}$ \\ ${ }^{1}$ Faculty of Economics, Universitas Negeri Semarang, Semarang, Indonesia \\ ${ }^{2}$ Faculty of Economics and Business, Universitas Muhammadiyah Surakarta, Surakarta, Indonesia \\ ${ }^{3}$ Doctoral Student, Faculty of Economics and Business, Universitas Sebelas Maret, Surakarta, Indonesia \\ ${ }^{4}$ Faculty of Economics and Business, Universitas Sebelas Maret, Surakarta, Indonesia \\ *Corresponding author: hasanmukhibad@mail.unnes.ac.id
}

\begin{abstract}
Sharia banks and conventional banks have real differences in their objectives and operations. Therefore, performance measurements must differentiated between Sharia banks and conventional banks. One performance measure recommended by researchers is performance-based on the Maqasid sharia Index (MSI). This study is to prove the influence of the Sharia Supervisory Board attributes (number of meetings, level of education, cross-membership) and commissioners' attributes (ratio of independent commissioners, number of members, number of meetings) to performance based on MSI. The research sample is 12 Sharia banks in Indonesia during the 2014-2018 observation year. The data analysis method uses panel data analysis with a fixed effect model. We find that SSB education level and independent board ratio had a negative effect on performance based on MSI. Cross-membership; the number of SSB meetings, board size, number of board meetings, and total assets does not affect performance based on MSI. This finding indicates that MSI has not become one of the goals that must be achieved in the management of Sharia banks in Indonesia. This is because the MSI score is still low. In addition, the dominance of debt financing is a characteristic that banks prefer transactions that generate fixed income and avoid transactions that use a fairer system, i.e. the Profit and Loss Sharing system. We recommend for regulators to develop different measurement tools from conventional banks and in accordance with the objectives of sharia implementation as sharia bank business operations (maqasid sharia). Future researcher can study and develop other measurement tools in formulating maqasid sharia by involving regulators, business actors, and experts so that the produced maqasid sharia indicators can be applied by banks.
\end{abstract}

Keywords: Maqasid sharia Index; Corporate Governance, Sharia Supervisory Board Attributes, Board Attributes JEL Classification Code: G30

DOI: 10.20885/isb.vol24.iss2.art2

\section{Introduction}

The impetus of a Sharia institution is a consequence of Muslim's needs to require transactions that are in accordance with Sharia, i.e. Sharia banks that do not practice usury, maysir, gharar and transaction related to haram goods and services. Therefore, there is religious motivation in the establishment of Sharia banks.

Philosophically, Sharia banks use a spiritual/transcendental approach to finance that combines the elements of logic and market values, religion, and social welfare (Hidayah, Lowe, \& Woods, 2019). The philosophical difference between Sharia banks and conventional banks is also seen in the differences in objectives, i.e. the purpose of obtaining falah (victory in the world and the hereafter) (Abdul-Baki \& Uthman, 2017). Laldin \& Furqani (2014) and Zainuldin, Lui, \& Yii (2018) assessed that Sharia banks are more promoting the socio-economic justice (adl) system, al-falah oriented, public interest (maslahah), and monotheism. Therefore, Sharia banks differ from conventional banks in practice, principles, and theory (Syafii, Sanrego, \& Taufiq, 2012; Mohammed, Tarique, \& Islam, 2015b). 
However, the measurement of the Sharia bank performance by several previous studies has been trapped in the use of the same financial ratios used by conventional banks (Syafii et al., 2012). Fah \& Hassani (2014), Qian \& Velayutham (2017), Milhem \& Istaiteyeh (2015) and Zarrouk, Ben Jedidia, \& Moualhi (2016) have used a financial ratio measurement tool to measure profitability and its comparison between Sharia banks and conventional banks. Another form is to use financial ratios to measure the level of efficiency between Sharia banks and conventional banks (see Pradiknas \& Faturohman, 2015; Yahya, Muhammad, \& Hadi, 2012; Ismail, Majid, \& Rahim, 2013; Prima Sakti \& Mohamad, 2018; Shawtari, Ariff, \& Abdul Razak, 2019). We consider that the above approach is certainly not appropriate because this method is not in line with the initial concept of establishing a Sharia bank in which there is a spirit to observe Islamic law in banking transactions.

Syafii et al. (2012) argue that Sharia provide alternatives using measurements based on the triple bottom line concept with performance indicators that include economic, environmental, and social indicators. Indicators that can cover the economic, environmental, and social aspects are Maqasid sharias (Syafii et al., 2012). Maqasid sharia strongly supports entities to achieve the welfare of all people, both in the world and in the hereafter ( $f a l a h)$. This goal has been assigned from God to mankind (khalifah fil ard). This mean that Sharia banks must be able to provide a role in improving the welfare of the people and reduce poverty in line with the bank's efforts to seek profits. As such, we use bank performance indicators based on Shariah principles as recommended by Syafii et al. (2012) and Mohammed et al. (2015b).

Our investigation of previous studies that conducted a study of maqasid sharias in Sharia banks is still limited to the following issues: measuring maqasid sharias in several banks, comparing maqasid sharia scores between banks, and it is still limited to limited research that explains the effect of corporate governance mechanisms on maqasid sharia index. Previous studies that examined performance based on Maqasid sharia only measured the size of Maqasid sharia index in the study sample and compared Maqasid sharia scores between banks and between countries (see Hurayra, 2015; Rusydiana \& Parisi, 2016; Syafii et al. 2012; Asutay \& Harningtyas, 2015; Mohammed et al., 2015b; Mohammad \& Shahwan; 2013). Research that examines the factors causing the high and low maqasid sharia scores in a bank is still limited. We found only Kholid \& Bachtiar (2015) and Mukhibad (2019) who examine the influence of the GCG mechanism on the performance of maqasid sharia. Kholid \& Bachtiar (2015) by using a sample of 7 Sharia banks in Indonesia found that the number of commissioners had a positive influence on maqasid performance, the number of audit committees had a negative influence on maqasid performance and the number of SSBs did not have a significant effect on maqasid performance. Sementara itu, Meanwhile, Mukhibad (2019) used a number of variables to measure the performance of Maqasid sharia and found that corporate governance mechanism and SSB did not affect maqasid sharia. In his research, Mukhibad (2019) measured maqasid sharia based on maqasid sharia disclosure, but Kholid \& Bachtiar (2015) measured maqasid sharia based on financial ratios.

This study was conducted to complement the previous research, i.e. the study of Kholid \& Bachtiar (2015) which only used the number of commissioners, audit committees, and SSB. From the previous studies, there are weaknesses in using numbers as indicators to measure the effectiveness of the work of the board. Large numbers of boards are very effective in large companies because these companies need special advice, but large numbers of boards are very likely to result in free-riding thereby reducing the quality of assessment (Coles, Daniel, \& Naveen, 2008; Farag, Mallin, \& OwYong, 2018). We complement the indicators for measuring the effectiveness of the board by using the number of meetings, education level, and cross membership.

This study is presented in several sections. Our first part reviews the study of the need for new performance evaluations and in line with the concept of sharia entities. The second part of the study is on measuring performance and developing hypotheses, followed by research methods. In the next section, we present the results of research and discussion and then conclusions and recommendations. 


\section{Literature Review}

\section{Stakeholders Theory, Islamic Enterprise Theory, and Maqasid Syariah}

An entity is a collection of many parties with many interests. Business can be understood as a set of values that creates relationships between groups within an entity. This mean that the business explains how customers, suppliers, owners, creditors, employees, the public, and managers interact to create company value. Therefore, the manager's job is actually to manage this relationship (Freeman, 2017) or also called as maintaining the fulfillment of all stakeholders' interests. Freeman, Harrison, Wicks, Parmar, \& Colle (2010) contend that the goal of stakeholder theory is to create value for all stakeholders.

Sharia entities have broader stakeholders than other entities. This is because, in sharia entities, the management of company resources must be in accordance with general rules (laws and other regulations) and rules from God (sharia). Therefore, in Sharia entities, the responsibility of managing the company is to all stakeholders, including God (Mukhibad, 2019). Even in the context of sharia, fulfillment of God's law must take precedence over other interests. The realization of this concept is sharia compliance with a transaction is the main factor of sharia entity in making company policies.

The theoretical, philosophical, objective, and operational differences between Sharia entities and conventional entities should also differ in performance measurement (Syafii et al., 2012). Previous researchers who examined the performance of Sharia banks are trapped in measurements using the same financial ratios as conventional banks. This approach is certainly not appropriate because it uses entity performance measurement tools that are not in line with the objectives of the sharia entity (Syafii et al., 2012; Hartono \& Sobari, 2017; Mukhibad, 2019).

In the introduction, we have written that maqasid sharia is an indicator that can be used as one of the solutions in measuring the performance of Sharia banks which is in line with the objectives of establishing Sharia banks. The basis used to develop this measurement model is the principle used by Sharia banks. This is by using Islamic law, so that performance measurement must also be in line with the objectives of sharia (maqasid sharia) (Hurayra, 2015; Mohammed, Tarique, \& Islam, 2015a).

When viewed in terms of language, maqasid sharia means the purpose of the implementation of Sharia-Islamic law (Mukhibad, 2019; Soleh, 2016). The purpose of Sharia is to improve the welfare of the community by protecting its faith (din), lust (nafs), reason ('aql), descent (nasi), and wealth (mal) (Asutay \& Harningtyas, 2015; Mohammad \& Shahwan, 2013; Mohammed et al., 2015a; Rusydiana, 2016; Shinkafi, Ali, \& Choudhury, 2017; Sutrisno; Widarjono, 2017; Syafii et al., 2012; Tarique \& Ahmed, 2017).

There are several methods in measuring the level of maqasid sharia. The first method is to measure maqasid sharia index based on bank disclosures in the annual report. This method is done by counting the number of disclosures on the predetermined indicators. Disclosure indicators include justice, individual educating, and public interest (Mukhibad, 2019). These methods have been used by Asutay \& Harningtyas (2015); andMukhibad (2019).

The second method is to operationalize the maqasid sharia indicators in the form of financial ratios. Mohammed, Razak, \& Taib (2008) introduce maqasid sharia index. In this method, Mohammed et al. (2008) applied Maqasid sharia indicators in several financial ratios. This measurement method has also been used by Rusydiana \& Parisi (2016), Hartono \& Sobari (2017), Syafii et al. (2012), and Kholid \& Bachtiar (2015). We consider that the two measurement methods above were developed for different purposes. Maqasid sharia measurements based on disclosure are used to evaluate the effectiveness of communication between banks and stakeholders through their annual reports, while the measurement ratio approach emphasizes more on evaluating the level of achievement of bank performance. This study uses a financial ratio approach because it is aligned with the research objectives. In addition, maqasid performance evaluation based on the announcement by looking at corporate governance has been carried out by Mukhibad (2019), although there are different measurements of corporate governance performed by Mukhibad (2019) within this study. 
In sharia bank management, it has a unique board-the sharia supervisory board (SSB).The studies uncover that SSB is empiricallyuseful to conduct monitoring and management consultancy in managing the company (Almutairi \& Quttainah, 2016; dan Farook et al., 2011). In line with Law number 21 of 2008 concerning Sharia Banking, it is stated that SSB is needed to guarantee the operation of banks in accordance with Islamic law. However, the role of SSB is also in improving the quality of financial statements (Rini, 2014), reducing earnings management (Mersni \& Ben Othman, 2016); increasing profitability (Nomran, Haron, \& Hassan, 2017; Shittu et al., 2016). The effectiveness of SSB in performing its duties depends on the number of SSB meetings, SSB Education level, and SSB cross membership.

SSB performs its duties as supervisor and provides consulting services to bank managers. Coordination between SSB and management allows it to produce policies or even new products that are of interest to customers. Therefore, often the SSB in performing consulting and supervision services (as measured by the number of meetings) will have an impact on performance. The number of SSB meetings was not been widely used by previous researchers as an indicator to measure the effectiveness of SSB. However, Hameed, Wirman, Alrazi, Nazli, \& Pramono (2004) assess that the number of SSB meetings is an indicator that can convince stakeholders that bank operations are in line with sharia rules. Therefore, the following hypothesis can be developed.

$\mathrm{H1}$ : The number of SSB meetings has a positive and significant relationship to performance based on the maqasid shariah index.

In addition to the number of meetings, the effectiveness of SSB in performing their duties is influenced by their educational background and education level. The level and background of SSB Education in accordance with the required competencies will certainly have an impact on the increasingly high quality of services provided by SSB. In contrast to the number of meetings, the educational background and level of SSB education have been widely used in previous studies such as Nurkhin, Rohman, Rofiq, \& Mukhibad (2018) who found that SSB's educational background had a positive influence on the performance of zakat. Nomran et al. (2017) and Nomran, Haron, \& Hassan (2018) found that SSB Education qualifications had a significant influence on profitability. Meanwhile, Safiullah \& Shamsuddin (2018) found that the risks of bank operations and bankruptcy would decrease often with an increase in the qualification of SSB education. Therefore, we can develop the following hypothesis:

H2: SSB Education Qualification has a positive influence on performance based on the maqasid shariah index.

Another indicator commonly used by previous researchers in measuring SSB performance is cross membership. This SSB cross membership positively influences their efficiency by increasing their knowledge and experience, and then improving the quality of services provided and subsequently improving bank performance. This cross-bank SSB membership allows them to give advice to one bank to adopt a strategy or product that SSB meets in other banks. There is evidence that cross-directors increase information transparency through comparing knowledge obtained from other companies and because decisions made in one board can be a part of the information for decisions in other boards (El-Halaby \& Hussainey, 2016). Nomran et al. (2018) have provided evidence that SSB cross membership has a positive influence on ROA. Therefore, the following hypothesis can be developed:

H3: SSB cross membership has a positive influence on performance based on the maqasid shariah index.

Agency theory assumes that the greater number of board of commissioners will reduce agency costs and improve coordination among the board of commissioners (Quttainah, Song, \& Wu, 2011) and reduce information asymmetry (Nawaz, 2019). These assumptions present a consequence that 
Sharia banks that have a large number of commissioners will perform better (Quttainah et al., 2011). Commissioners who have diverse backgrounds and a large number will enable the emergence of transfer of knowledge between them and will further increase their knowledge. Further effects will certainly improve bank performance. However, it must be monitored, that a large commissioner will incur coordination costs and may lead to a free rider. If this happens, then a large number of commissioners has a negative impact on performance. However, Basuony, Mohamed, \& Al-Baidhani (2014) found that the number of boards had a positive influence on Tobin-Q, ROA and ROE (Almutairi \& Quttainah, 2017). Meanwhile, Guest (2009) states that the number of commissioners has a negative impact on ROA. Bukair \& Abdul Rahman (2015) found that the size of the board of commissioner influences ROE, but does not influence ROA. Based on previous studies there are those that have proven the relationship between board size and firm performance. However, Coles et al. (2008) argue that the relationship between the two depends on the company's economic environment. For example, companies with greater advisory needs (such as diversified companies and high debt) can benefit from a bigger board (Pathan \& Faff, 2013). Sharia banks have more complex operations (Mollah, Hassan, Farooque, \& Mobarek, 2017), so it requires a bigger board (Mollah \& Zaman, 2015). Therefore, we develop the following hypothesis:

H4: The number of commissioners board has a positive influence on performance based on the maqasid shariah index

Banks that have a large ratio of independent commisioners board will reduce information asymmetry between management and owners as well as between majority owners and minority owners. The existence of an independent commissioner is very important in managing a company (Zhang, Cheong, \& Rasiah, 2018). However, the role of independent boards in improving performance still results in mixed findings (Zhang et al., 2018). The findings of Pathan \& Faff (2013) and Adewuyi \& Olowookere (2008) reject the assumption of agency theory assumption that the existence of an independent commissioner will improve performance. However, in the corporate governance structure of companies with scattered ownership, an independent commissioner is needed to ensure the interests of minority owners and stakeholders. Therefore, we develop a hypothesis:

$\mathrm{H} 5$ : The ratio of independent commissioners board has a positive influence on performance based on the maqasid shariah index

Similar to SSB, the commissioner also has the function to conduct supervision and consultation. This consultation was carried out during the meeting between the commissioners and management. The high number of meetings indicated that the commissioners had carried out their duties. This means that the number of commissioners' meetings can be used to assess the effectiveness of supervision and the provision of consultations by the commissioners (Carausu, 2015).

In this study, we predict a positive relationship between the number of commissioners' meetings and performance. Commissioners who have the task of providing advice and supervisors on management policies and conducting meetings between commissioners and directors are one of the ways for commissioners to perform their duties. Therefore, the more often they do meetings, the greater the role of the commissioner in monitoring activities. Some researchers, likeJizi, Salama, Dixon, \& Stratling (2014) and Kent \& Stewart (2008) have proven this hypothesis. Therefore, we developed the following hypothesis:

H6: The number of commissioners' meetings with directors has a positive influence on performance based on the maqasid shariah index

The amount of assets is the amount of available resources used by the company in running its business. Large resources will increase the ability of banks to earn revenue. Therefore, the amount of assets has a positive influence on performance. Previous studies found a relationship between the amount of assets with profitability (Hakimi, Rachdi, Ben Selma Mokni, \& Hssini, 2018; 
Hirindukawshala, 2017); information disclosure (Magness, 2006); CSR (Magnanelli \& Izzo, 2017), and CSR disclosure (Wuttichindanon, 2017). We have inducted the various forms of performance measures in the form of another performance measure-the Maqasid sharia. Therefore, we develop the following hypothesis:

H7: Bank size has a positive influence on performance based on the maqasid shariah index

\section{Methods}

The study uses a sample of Islamic commercial banks in Indonesia, amounting to 12 banks with a 5year observation period, 2014 to 2018. The research sample was determined by purposive sampling method. Data were analyzed using panel data regression method with fixed effect model approach. The method was chosen after conducting a Chow-test and Hausman-test.

Performance variables based on maqasid shariah are calculated on average from three indicators after weighting is calculated. The three indicators are:

Table 1. Maqasid sharia index Indicator

\begin{tabular}{lllc}
\hline \multicolumn{1}{c}{ Indicator } & \multicolumn{1}{c}{ Element } & \multicolumn{1}{c}{ Performance Ratio } & $\begin{array}{c}\text { Weight } \\
(\%)\end{array}$ \\
\hline a. Education & E1: Educational Grant & R1: Educational grant/fee & 24 \\
& E2: Research & R2: Research costs/total costs & 27 \\
& E3: Training & R3: Training costs/total costs & 26 \\
& E4: Publication & R4: Cost of publication/total cost & 23 \\
& Total & & 100 \\
\hline b. Justice* & E6: Functional distribution & 6: Total profit-sharing financing/Total Financing & 45,71 \\
& E7: Non-interest Bank Products & R7: Interest income/Total income & 54,29 \\
& Total & R8: ROA & 100 \\
\hline c. Wellbeing & E8: Profit Ratio & R9: Zakah/Net Profit & 33 \\
& E9: Income Transfer & & 30 \\
& E10: Investment ratio in the real & R10: Real sector investment/Total investment & \\
& sector & & 37 \\
& Total & & 100 \\
\hline
\end{tabular}

* R5: Fair return ratio cannot be used in Indonesia because it includes publicly listed Sharia banks in Indonesia. Therefore, the Fair Return performance (30\%) is divided into the other two indicators.

Maqasid sharia index is calculated with the following formula:

MQI $=(30 \% x$ Education score $)+(41 \% x$ Justice Score $)+(29 \% x$ Welfare score $)$

The independent variable is measured by:

a. The number of SSB meetings is measured based on the number of SSB real meetings (frequency) in one year.

b. The level of SSB education is measured by giving a weight of 1 if SSB has a Bachelor's education, a weight of 2 if SSB has a master's degree and a weight of 3 if SSB has a doctoral degree. The Education level score is calculated from the average Education score across the entire SSB.

c. SSB cross membership is measured by calculating the average of the number of duplicate SSB positions.

d. Independent commissioners are measured by the ratio of the number of independent commissioners to all commissioners.

e. Board size is measured by the number of board of commissioners owned by the bank.

f. The number of commissioners' meetings is measured by the total number of meetings (frequency) of the commissioners in one year.

g. Size is measured by the number of log assets 


\section{Results and Discussion}

In this section, we present a descriptive analysis of each variable used:

Table 2. Descriptive Statistics of Research Variables

\begin{tabular}{lrrrrrrrr}
\hline Indicator & MSI & $\begin{array}{c}\text { SSB } \\
\text { Meeting }\end{array}$ & $\begin{array}{c}\text { Cross } \\
\text { Membership }\end{array}$ & $\begin{array}{c}\text { Education } \\
\text { Level }\end{array}$ & $\begin{array}{c}\text { Independent } \\
\text { Board (\%) }\end{array}$ & $\begin{array}{c}\text { Board } \\
\text { Size }\end{array}$ & $\begin{array}{c}\text { Board } \\
\text { Meeting }\end{array}$ & $\begin{array}{c}\text { Assets } \\
\text { (Million } \\
\text { IDR) }\end{array}$ \\
\hline Min & 12.6392 & 6 & 1.5 & 1 & 0 & 2 & 2 & 661,912 \\
Max & 48.9029 & 30 & 5.5 & 3 & 1.5 & 6 & 23 & $98,341,116$ \\
Mean & 31.6043 & 13.71667 & 3.211111 & 2.341667 & 0.671734 & 3.75 & 9.883333 & $18,779,630$ \\
St. Dev & 9.4193 & 4.042535 & 0.985233 & 0.47083 & 0.250538 & 0.967699 & 5.511442 & $23,726,185$ \\
\hline
\end{tabular}

Table 4 shows that banks in Indonesia have the maqasid sharia performance which still tends to be low at $31.60 \%$. The number of Sharia bank's SSB meetings in Indonesia is above the standard, which is 12 times a year. The realization is that SSB has meetings with an average of more than 13 times in one year. The level of double occupation of SSB in Indonesia is relatively high, with an average SSB occupying more than 3 Sharia financial institutions. As a result, transfer of information and knowledge may occur between them. However, a large cross membership has a negative impact, i.e. the less time provided by an SSB in providing services to one of the Sharia banks.

SSB in Indonesia, in terms of Education level, is also classified as quite good, i.e. by having an average level of Masters education and many are also holding a doctorate degree. This condition will also improve the quality of services provided. The structure of commissioners is occupied by a majority of independent commissioners with an average number of commissioners of more than 3 people. The average number of commissioners' meetings is more than 9 meetings in 1 year. The frequency of commissioner council meetings is also quite high because it is above the minimum standard of only 6 meetings in 1 year.

The results of the statistical test with the panel data regression analysis approach using the fixed effect model are as follows:

Table 3. FEM Model Test Results

\begin{tabular}{lcccc}
\hline \multicolumn{1}{c}{ Variables } & Coefficient & Std. Error & t-Statistic & Prob. \\
\hline SSB Meeting & -0.0026 & 0.0017 & -1.5638 & 0.1256 \\
SSB Education & -0.0444 & 0.0245 & -1.8169 & 0.0765 \\
Cross Membership of SSB & 0.0020 & 0.0094 & 0.2132 & 0.8322 \\
Independent Board Ratio & -0.0737 & 0.0369 & -1.9970 & 0.0525 \\
Board Size & 0.0085 & 0.0137 & 0.6225 & 0.5371 \\
Board Meeting & -0.0018 & 0.0012 & -1.5631 & 0.1257 \\
Size & 0.0646 & 0.0516 & 1.2525 & 0.2175 \\
Constant & -0.3521 & 0.6665 & -0.5283 & 0.6001 \\
\hline
\end{tabular}

Based on table 3, the following points can be concluded in the acceptance and rejection hypothesis table 4. It shows that all hypotheses developed in this study were rejected. These findings provide the conclusion that the concept of maqasid sharia measured by the model developed by Mohammed et al. (2008) has not been used by bank managers as a performance indicator to be achieved by Sharia banks.

The first corporate governance mechanism used in this study was SSB measured by the frequency of SSB meetings, SSB Education level, and the average of double occupation of SSB. In general, all indicators used to measure the effectiveness of SSB in performing their duties to improve bank performance based on Shariah principles have not been proven statistically. These findings also 
support the findings of Kholid \& Bachtiar (2015) which measures the effectiveness of SSB with the number of SSB also shows there is no relationship between the number of SSB and the performance of the maqasid sharia. Mukhibad's (2019) finding also supports the findings of this study. Using a more complex measure in measuring SSB, which includes the number of SSBs, frequency of meetings, cross membership, SSB expertise, and the level of SSB Education simultaneously does not influence the performance of maqasid sharia. However, maqasid shariah measurements used by Mukhibad (2019) based on disclosures in the annual report are different from studies based on financial ratios.

Table 4. Table of Hypotheses Acceptance or Rejection

\begin{tabular}{|c|c|}
\hline Hypotheses & Conclussion \\
\hline $\begin{array}{l}\text { H1: The number of SSB meetings has a positive and significant relationship to performance } \\
\text { based on the maqasid shariah index }\end{array}$ & Reject \\
\hline $\begin{array}{l}\text { H2: SSB Education Qualification has a positive influence on performance based on the maqasid } \\
\text { shariah index }\end{array}$ & Reject* \\
\hline $\begin{array}{l}\text { H3: SSB cross membership has a positive influence on performance based on the maqasid } \\
\text { shariah index }\end{array}$ & Reject \\
\hline $\begin{array}{l}\text { H4: The number of commissioner board has a positive influence on performance based on the } \\
\text { maqasid shariah index }\end{array}$ & Reject \\
\hline $\begin{array}{l}\text { H5: The ratio of independent commissioner board has a positive influence on performance based } \\
\text { on the maqasid shariah index }\end{array}$ & Reject* \\
\hline $\begin{array}{l}\text { H6: The number of commissioners' meetings with directors has a positive influence on } \\
\text { performance based on the maqasid shariah index }\end{array}$ & Reject \\
\hline H7: Bank size has a positive influence on performance based on the maqasid shariah index & Reject \\
\hline
\end{tabular}

Significant at the level of $10 \%$, and has a negative coefficient

There is an interesting finding from this study, which the level of SSB Education has a fairly strong and negative influence on the performance of maqasid sharia. This finding implies that the high level of SSB Education has encouraged banks to stay away from maqasid sharia. If we pay attention, most of the financial ratios used in measuring the maqasid sharia of Sharia banks in Indonesia are still low. For example, the financing structure channeled by Sharia banks in Indonesia is still dominated by murabahah financing that has fixed income (Anisykurlillah \& Mukhibad, 2018). The reality of high fixed income based financing and the low profit and loss sharing (PLS) based financing indicates that Sharia banks are still practicing Islamic law in a false manner (Hidayah et al., 2019). Even this phenomenon has a tendency that there is no difference between Sharia banks and conventional banks (Chong \& Liu, 2009). The dominant reason for fixed income financing is because of risk reasons. This PLS financing has a greater risk than fixed income financing. Therefore, Sharia banks that have SSBs with a high level of education may be able to further enhance bank operations in the direction of achieving better economic performance. This possibility also occurs in the indicators of Education (workshop, training) and welfare (zakat and investment in the real sector), which in our opinion can reduce economic performance.

Table 4 also shows that all indicators that we use in measuring the effectiveness of the board of commissioners in performing their duties (including the number of meetings, the number of commissioners, and the ratio of independent commissioners) in general also do not have a positive influence on the performance of the maqasid sharia. These findings reject the findings of Kholid \& Bachtiar (2015) which found that the number of the board of commissioners had a positive influence on the maqasid sharia. Differences in the results of this study with the study of Kholid \& Bachtiar (2015) is located in the method of analyzing data. Kholid \& Bachtiar (2015) Used a regression (or common effect model) that tends not to pay attention to variations in data between banks, but this study uses FEM that pays attention to variations in data between banks. From the results of the chow test, we found that the fixed effct model is the best model rather than the random effect model or the common effect model. However, Mukhibad (2019) using the ratio of independent commissioners, the 
number of audit committees, and the frequency of commissioners meetings found that all of these variables did not have a maqasid sharia disclosure. This means that this research verifies the results of Mukhibad's (2019) study.

Table 3 shows that the ratio of independent commissioners actually has a negative impact on the performance of the maqasid shariah. As we previously suspected, the majority of indicators used in measuring maqasid sharia are indicators which, if applied, would reduce banks' short-term economic performance. The presence of independent commissioners used to reduce agency conflicts between majority owners and minority owners prioritizes the economic performance of banks in the short term. This is because the sustainability of bank ownership by minority owners is not as long as the majority owner. This minority owner buys shares for short-term purposes.

The results also showed that the size of the bank did not have a positive influence on the performance of the maqasid sharia. This finding reinforces the previous assumption that the maqasid sharia has not been an indicator of the performance to be achieved by Sharia banks in Indonesia. Sharia banks are still dominant in achieving economic performance. The condition of customers who tend to be rational (economic eriented) coupled with competition from Sharia banks and conventional banks in Indonesia (dual system banking) have encouraged Sharia banks to have competitive economic performance.

\section{Conclusion}

In general, the results of this study indicate that SSB and commissioners do not have a positive impact on the performance of Sharia banks based on maqasid sharia. In addition, the size of the bank is also not as one of the factors that has a positive influence on the performance of maqasid sharia. In addition, the level of SSB Education and the ratio of independent commissioners actually have a negative influence on the performance of maqasid sharia. Our guess is that the majority of financial ratios used in measuring maqasid sharia have a tendency to reduce the bank's economic performance in the short term, so that Sharia banks that have SSBs with doctoral education levels and Sharia banks that have a large independent commissioner ratio tend to avoid them. This means that short-term economic performance is preferred to the maqasid sharia performance. The results of this study also lead to the understanding that the concept of maqasid sharia (limited to the measurement tools we use) have not yet been fully appliedby the Sharia banks as an indicator of theirperformance.

This study measures the performance of maqasid sharia developed by Mohammed et al. (2008). This model may still be in the form of a concept and needs to be discussed by the regulators, actors, and the Sharia supervisory board. This is due to the continuing discussion with the maqasid sharia indicator as a tool for evaluating bank performance. Therefore, further research can develop a maqasid shariah model that could be more acceptable to be applied in Indonesia. In addition to the development of maqasid sharia indicators, researchers can then compare performance measurements based on maqasid sharia with accounting-based performance indicators and explain which performance is more used by Sharia bank players.

\section{References}

Abdul-Baki, Z., \& Uthman, A. B. (2017). Exploring The "Social Failures" of Islamic Banks: A Historical Dialectics Analysis. Journal of Islamic Accounting and Business Research, 8(3), 250-271. https://doi.org/10.1108/JIABR-06-2014-0021

Adewuyi, A. O., \& Olowookere, A. E. (2008). Corporate governance and performance of Nigerian listed firms: Further evidence. Corporate Ownership and Control, 6(2 D CONT. 3), 354-371.

Almutairi, A. R., \& Quttainah, M. A. (2017). Corporate governance: Evidence from Islamic banks. Social Responsibility Journal, 13(3), 601-624. https://doi.org/10.1108/SRJ-05-2016-0061

Anisykurlillah, I., \& Mukhibad, H. (2018). Empirical Proof of Traditional Market Trader Readiness in

122 (ㅇ 2020 The Authors. Jurnal Siasat Bisnis. Published by The Management Development Centre, Department of Management, Faculty of Business \& Economics, Universitas Islam Indonesia 
Preparing Financial Statement as a Mudharabah Transaction Media. Australasian Journal of Islamic Finance and Business, 4(1), 11-18.

Asutay, M., \& Harningtyas, A. F. (2015). Developing Maqasid al-Shari'ah Index to Evaluate Social Performance of Islamic Banks: A Conceptual and Empirical Attempt. International Journal of Islamic Economics and Finance Studies, 1(1), 5-64.

Basuony, M. A., Mohamed, E. K. A., \& Al-Baidhani, A. M. (2014). The effect of corporate governance on bank financial performance: Evidence from the Arabian Peninsula. Corporate Ownership and Control, 11(2 B), 178-191. https://doi.org/10.22495/cocv11i2c1p3

Bukair, A. A., \& Abdul Rahman, A. (2015). Bank performance and board of directors attributes by Islamic banks. International Journal of Islamic and Middle Eastern Finance and Management, 8(3), 291-309. https://doi.org/10.1108/IMEFM-10-2013-0111

Carausu, N. (2015). Monitor and Control in Companies: an Agency Theory Approach. Journal of Public Administration, Finance and Law, (2spec), 46-60.

Chong, B. S., \& Liu, M. H. (2009). Islamic banking: Interest-free or interest-based? Pacific Basin Finance Journal, 17(1), 125-144. https://doi.org/10.1016/j.pacfin.2007.12.003

Coles, J. L., Daniel, N. D., \& Naveen, L. (2008). Boards: Does one size fit all? Journal of Financial Economics, 87(2), 329-356. https://doi.org/10.1016/j.jfineco.2006.08.008

El-Halaby, S., \& Hussainey, K. (2016). Determinants of Compliance With AAOIFI Standards by Islamic Banks. International Journal of Islamic and Middle Eastern Finance and Management, 9(1), 143-168. https://doi.org/10.1108/IMEFM-06-2015-0074

Fah, C. F., \& Hassani, A. (2014). A Study of Islamic and Conventional Banks in Malaysia. JKAU: Islamic Econ, 27(1), 73-99. https://doi.org/10.4197

Farag, H., Mallin, C., \& Ow-Yong, K. (2018). Corporate governance in Islamic banks: New insights for dual board structure and agency relationships. Journal of International Financial Markets, Institutions and Money, 54, 59-77. https://doi.org/10.1016/j.intfin.2017.08.002

Farook, S., M, K. H., \& Lanis, R. (2011). Determinants of Corporate Social Responsibility Disclosure: The Case of Islamic Banks. Journal of Islamic Accounting and Business Research, 2(2), 114141. https://doi.org/10.1108/17590811111170539

Freeman, R. E. (2017). Five Challenges to Stakeholder Theory: A Report on Research in Progress. In Stakeholder Management (pp. 1-20). https://doi.org/10.1108/S2514-175920170000001

Freeman, R. E., Harrison, J. S., Wicks, A. C., Parmar, B., \& Colle, S. de. (2010). Stakeholder Theory The State of The Art (1st ed.). New York www.cambridge.org: United States of America by Cambridge University Press.

Guest, P. M. (2009). The impact of board size on firm performance: Evidence from the UK. European Journal of Finance, 15(4), 385-404. https://doi.org/10.1080/13518470802466121

Hakimi, A., Rachdi, H., Mokni, R. B. S., \& Hssini, H. (2018). Do board characteristics affect bank performance? Evidence from the Bahrain Islamic banks. Journal of Islamic Accounting and Business Research, 9(2), 251-272. https://doi.org/10.1108/JIABR-06-2015-0029

Hameed, S., Wirman, A., Alrazi, B., Nazli, M., \& Pramono, S. (2004). Alternative Disclosure and Performance Measures for Islamic Banks. Second Conference on Administrative Sciences: Meeting the Challenges of the Globalization Age, King Fahd University of Petroleum \& Minerals, Dhahran, Saudi Arabia, 19-21. https://doi.org/10.1017/CBO9781107415324.004

Hartono, S., \& Sobari, A. (2017). Sharia Maqashid Index As a Measuring Performance of Islamic 
Islamic corporate governance and performance based on maqasid sharia index- study in Indonesia

Banking: a More Holistic Approach. Corporate Ownership and Control, 14(2), 193-201. https://doi.org/10.22495/cocv14i2c1p5

Hidayah, N. N., Lowe, A., \& Woods, M. (2019). Accounting and pseudo spirituality in Islamic financial institutions. Critical Perspectives on Accounting, 61, 22-37. https://doi.org/10.1016/j.cpa.2018.09.002

Hirindukawshala, K. (2017). The Factors Effecting on Bank Profitability. International Journal of Scientific and Research Publications, 7(2), 212. Retrieved from www.ijsrp.org

Hisham Yahya, M., Muhammad, J., \& Razak Abdul Hadi, A. (2012). A comparative study on the level of efficiency between Islamic and conventional banking systems in Malaysia. International Journal of Islamic and Middle Eastern Finance and Management, 5(1), 48-62. https://doi.org/10.1108/17538391211216820

Hurayra, M. A. (2015). Achievement of Maqasid-al-Shari'ah in Islamic Banking: An Evaluation of Islami Bank Bangladesh Limited. Global Journal of Computer Science and Technology: A Hardware \& Computation, 15(1).

Ismail, F., Shabri Abd. Majid, M., \& Rahim, R. A. (2013). Efficiency of Islamic and conventional banks in Malaysia. Journal of Financial Reporting and Accounting, 11(1), 92-107. https://doi.org/10.1108/jfra-03-2013-0011

Jizi, M. I., Salama, A., Dixon, R., \& Stratling, R. (2014). Corporate Governance and Corporate Social Responsibility Disclosure: Evidence from the US Banking Sector. Journal of Business Ethics, 125(4), 601-615. https://doi.org/10.1007/s10551-013-1929-2

Kent, P., \& Stewart, J. (2008). Corporate governance and disclosures on the transition to International Financial Reporting Standards. Accounting and Finance, 48(4), 649-671. https://doi.org/10.1111/j.1467-629X.2007.00257.x

Kholid, M. N., \& Bachtiar, A. (2015). Good corporate governance dan kinerja maqasid syariah bank syariah di Indonesia. Jurnal Akuntansi \& Auditing Indonesia, 19(2), 126-136. https://doi.org/10.20885/jaai.vol19.iss2.art4

Laldin, M. A., \& Furqani, H. (2014). The Foundations of Islamic Finance and the Maqāṣid Al-Sharīah Requirements. Journal of Islamic Finance, 2(1), 31-37. https://doi.org/10.12816/0001115

Magnanelli, B. S., \& Izzo, M. F. (2017). Corporate Social Performance And Cost Of Debt: The Relationship. Social Responsibility Journal, 13(2), 250-265. https://doi.org/10.1108/SRJ-062016-0103

Magness, V. (2006). Strategic Posture, Financial Performance and Environmental Disclosure: An Empirical Test of Legitimacy Theory. Accounting, Auditing and Accountability Journal, 19(4), 540-563. https://doi.org/10.1108/09513570610679128

Mersni, H., \& Ben Othman, H. (2016). The impact of corporate governance mechanisms on earnings management in Islamic banks in the Middle East region. In Journal of Islamic Accounting and Business Research (Vol. 7). https://doi.org/10.1108/JIABR-11-2014-0039

Milhem, M. M., \& Istaiteyeh, R. M. S. (2015). Financial performance of islamic and conventional banks: evidence from jordan. Global Journal of Business Reseacrh, 9(3), 27-41.

Mohammad, M. O., \& Shahwan, S. (2013). The objective of islamic economic and islamic banking in light of maqasid al-shariah: A critical review. Middle East Journal of Scientific Research, 13(SPLISSUE), 75-84. https://doi.org/10.5829/idosi.mejsr.2013.13.1885

Mohammed, M. O., Razak, D. A., \& Taib, F. M. (2008). The Performance Measures of Islamic Banking 
Based on the Maqasid Framework. IIUM International Accounting Conference (INT AC IV), 1-17. Kuala Lumpur: Islamic International University Malaysia.

Mohammed, M. O., Tarique, K., \& Islam, R. (2015a). Measuring The Performance Of Islamic Banks Using Maqāṣid -Based Model. Intellectual Discourse, 23(Special Issue), 401-424.

Mohammed, M. O., Tarique, K. M., \& Islam, R. (2015b). Measuring the performance of Islamic banks using maqasid based model. Intellectual Discourse, 23(Spesial Issues), 401-424.

Mollah, S., Hassan, M. K., Farooque, O. Al, \& Mobarek, A. (2017). The Governance, Risk-taking, and Performance of Islamic Banks. Journal of Financial Services Research, 52(2), 1-29.

Mollah, S., \& Zaman, M. (2015). Shari'ah supervision, corporate governance and performance: Conventional vs Islamic banks. Journal of Banking \& Finance, 58, 418-435. https://doi.org/10.1016/j.jbankfin.2015.04.030

Mukhibad, H. (2019). The Role Of Sharia Supervisory Boards in Meeting Maqasid Syariah - Study on Islamic Banks in Indonesia. European Journal of Islamic Finance, 13(August), 1-10. https://doi.org/https://doi.org/10.13135/2421-2172/3620

Nawaz, T. (2019). Exploring the Nexus Between Human Capital, Corporate Governance and Performance: Evidence from Islamic Banks. Journal of Business Ethics, 157(2), 567-587. https://doi.org/10.1007/s10551-017-3694-0

Nomran, N. M., Haron, R., \& Hassan, R. (2017). Bank Performance and Shari'ah Supervisory Board Attributes of Islamic Banks: Does Bank Size Matter? Journal of Islamic Finance, 6(Special Issue), 174-187. https://doi.org/10.12816/0047348

Nomran, N. M., Haron, R., \& Hassan, R. (2018). Shari'ah supervisory board characteristics effects on Islamic banks' performance: Evidence from Malaysia. International Journal of Bank Marketing, 36(2), 290-304. https://doi.org/10.1108/JJBM-12-2016-0197

Nurkhin, A., Rohman, A., Rofiq, A., \& Mukhibad, H. (2018). The role of the Sharia Supervisory Board and corporate governance mechanisms in enhancing Islamic performance-evidence from Indonesia. Banks and Bank Systems, 13(4), 85-95. https://doi.org/10.21511/bbs.13(4).2018.08

Pathan, S., \& Faff, R. (2013). Does board structure in banks really affect their performance? Journal of Banking and Finance, 37(5), 1573-1589. https://doi.org/10.1016/j.jbankfin.2012.12.016

Pradiknas, T. Y., \& Faturohman, T. (2015). Efficiency of Islamic Banking Compared To Conventional Banking: Eveidence From Indoensian Banking Sector. Journal of Business and Management, 4(5), 540-551.

Qian, D. J., \& Velayutham, S. (2017). Conventional Banking and Islamic Banking: Do the Different Philosophies Lead to Different Financial Outcomes? Journal of Wealth Management \& Financial Planning, 4(June), 3-14. Retrieved from https://www.islamicfinance.com/2014/12/

Quttainah, M. A., Song, L., \& Wu, Q. (2011). Do Islamic Banks Employ Less Earnings Management? Do Islamic Banks Employ Less Earnings Management? Politics and Conomics Development ERF 17th Annual Conference 2011. https://doi.org/10.2139/ssrn.2283968

Rini. (2014). The Effect of Audit Committee Role and Sharia Supervisory Board Role on Financial Reporting Quality At Islamic Banks In Indonesia. Journal of Economics, Business, and Accountancy Ventura, 17(1), 145-156. https://doi.org/10.14414/jebav.14.170113

Rusydiana, A. (2016). The Measurement of Islamic Bank Performance: A Study Using Maqasid Index and Profitability. Global Review of Islamic Economics and Business, 4(1), 1-14. 
Rusydiana, A. S., \& Parisi, S. Al. (2016). The Measurement of Islamic Bank Performance: A Study Using Maqasid Index and Profitability. Global Review of Islamic Economics and Business, 4(1), 1-14.

Safiullah, M., \& Shamsuddin, A. (2018). Risk in Islamic Banking and Corporate Governance. PacificBasin Finance Journal 47, 47, 129-149. https://doi.org/10.1016/j.pacfin.2017.12.008

Sakti, M. R. P., \& Mohamad, A. (2018). Efficiency, stability and asset quality of Islamic vis-à-vis conventional banks: Evidence from Indonesia. Journal of Islamic Accounting and Business Research, 9(3), 378-400. https://doi.org/10.1108/JIABR-07-2015-0031

Shawtari, F. A., Ariff, M., \& Razak, S. H. A. (2019). Efficiency and bank margins: a comparative analysis of Islamic and conventional banks in Yemen. Journal of Islamic Accounting and Business Research, 10(1), 50-72. https://doi.org/10.1108/JIABR-07-2015-0033

Shinkafi, A. A., Ali, N. A., \& Choudhury, M. (2017). Contemporary Islamic Economic Studies on Maqasid Shari'ah: A Systematic Literature Review. Humanomics, 33(3), 315-334. https://doi.org/10.1108/H-03-2017-0041

Shittu, I., Ahmad, A. C., \& Ishak, Z. (2016). Board Characteristics and Earnings Per Share of Malaysian Islamic Banks. International Journal of Economics and Financial Issues, 6(S6), 135-137.

Soleh, I. (2016). The Impact of Maqasid Syariah and Core Competency on Performance of Islamic Bank. International Journal of Economics, Commerce and Management, IV(10), 872-880.

Sutrisno; Widarjono, A. (2017). Islamic Bank Performance: Between Maqasid sharia and Camels Model. International Journal of Economics, Business and Management Research, 1(04), 562574.

Syafii, M., Sanrego, Y. D., \& Taufiq, M. (2012). An Analysis of Islamic Banking Performance: Maqashid Index Implementation in Indonesia and Jordania. Journal of Islamic Finance, 1(1), $12-29$.

Tarique, K., \& Ahmed, M. U. (2017). Maqasid al-Shariah in CSR Practices of the Islamic Banks: A Case Study of IBBL. Journal of Islamic Economics, Banking and Finance, 13(3), 47-63.

Wuttichindanon, S. (2017). Corporate social responsibility disclosure-choices of report and its determinants: Empirical evidence from firms listed on the Stock Exchange of Thailand. Kasetsart Journal of Social Sciences, 38(2), 156-162. https://doi.org/10.1016/j.kjss.2016.07.002

Zainuldin, M. H., Lui, T. K., \& Yii, K. J. (2018). Principal-agent relationship issues in Islamic banks: a view of Islamic ethical system. International Journal of Islamic and Middle Eastern Finance and Management, 11(2), 297-311. https://doi.org/10.1108/IMEFM-08-2017-0212

Zarrouk, H., Jedidia, K. Ben, \& Moualhi, M. (2016). Is Islamic bank profitability driven by same forces as conventional banks? International Journal of Islamic and Middle Eastern Finance and Management, 9(1), 46-66. https://doi.org/10.1108/IMEFM-12-2014-0120

Zhang, C., Cheong, K. C., \& Rasiah, R. (2018). Board independence, state ownership and stock return volatility during Chinese state enterprise reform. Corporate Governance (Bingley), 18(2), 220-232. https://doi.org/10.1108/CG-08-2016-0172 